\title{
PENGARUH ARUS KAS KEGIATAN OPERASI, SIKLUS OPERASI, UKURAN PERUSAHAAN DAN TINGKAT HUTANG TERHADAP PERSISTENSI LABA (STUDI EMPIRIS PADA PERUSAHAAN JASA SUB SEKTOR KONSTRUKSI DAN BANGUNAN YANG TERDAFTAR DI BURSA EFEK INDONESIA PERIODE 2013-2016)
}

\author{
Varadika Sarah', Ahmad Jibrail, S.E.M.A ${ }^{2}$, Sudrajat Martadinata, M.S.A ${ }^{3}$ \\ 1,2,3 Faculty of Economic and business, Sumbawa University of Tecnology \\ Email: varadikasarah@gmail.com, ahmad.jibrail@uts.ac.id, sudrajat.martadinata@uts.ac.id
}

\begin{tabular}{|c|c|}
\hline \multicolumn{2}{|r|}{ ABSTRACT } \\
\hline $\begin{array}{l}\text { Diterima: } \\
\text { Januari } 2019\end{array}$ & $\begin{array}{l}\text { Earnings Persistence is earning can reflect the earnimg priod next. In fact there are } \\
\text { still companies that do not guarantee a persistent of earning. This study wished to } \\
\text { examine ehe effect of operating cash flows, operating cycle, firm size, and the lever of }\end{array}$ \\
\hline Diterbitkan: & debt both individually and simultaneously to earning persistence in service compnies \\
\hline Februari 2019 & $\begin{array}{l}\text { of construction and building sector listed on Indonesia Stock Exchange period 2013- } \\
2016 \text {. The sampling technique using purposive sampling so than } 9 \text { sample companies }\end{array}$ \\
\hline $\begin{array}{l}\text { Keywords: } \\
\text { Cash Flow }\end{array}$ & $\begin{array}{l}\text { were obtained. Data were analized using panel data with multiple regression then } \\
\text { tested with the help of STATA } 11 \text { softwere. }\end{array}$ \\
\hline $\begin{array}{l}\text { Cycle, Firm } \\
\text { Size, Debt, } \\
\text { Earning } \\
\text { Persistence }\end{array}$ & $\begin{array}{l}\text { The result of this study are: operating cash flow, operating cycle, firm size there is not } \\
\text { significant effect on earning persistence. While the level of debt has significant effect } \\
\text { on earning persistence in service compnies of construction and building sector listed } \\
\text { on Indonesia Stock Exchange period } 2013-2016 \text {. }\end{array}$ \\
\hline
\end{tabular}

\section{PENDAHULUAN}

Para pemakai laporan keuangan menilai bahwa tingginya laba berarti usaha atau perusahaan dalam kondisi fit tanpa berpikir bagaimana proses laba tersebut diperoleh dan apakah laba tersebut adalah laba yang berkelanjutan. Banyak pemilik perusahaan terlalu fokus pada pundi-pundi hasil penjualan yang meningkat setiap periode. Akibat dari hanya mementingkan pada hasil lebih selisih pendapatan dengan beban-beban tanpa melihat aliran kas yang berada direkening dan kualitas laba itu sendiri.

Septavita, (2016) menyatakan semakin tinggi laba yang dihasilkan maka semakin baik pula kinerja suatu perusahaan. Para pengguna laporan keuangan yang masing-masing memiliki kepentingan yang berbeda dalam menggunakan informasi laba mengandalkan informasi yang tersaji dalam laporan keuangan sebagai sumber pengambilan keputusannya sehingga dari sini dapat dilihat kualitas dari laba tersebut terutama tingkat persistensi labanya.

Berbicara tentang persistensi laba berarti dapat dikatakan laba tersebut berkualitas karena persistensi laba merupakan salah satu komponen dari kualitas laba. Laba yang semakin berkualitas berbanding terbalik dengan kemungkinan laba tersebut dimanipulasi. Faktanya PT. Adhy Karya (Persero) Tbk dengan kode saham ADHI tidak menjamin laba yang persistensi karena mencatat kineja yang kurang cemerlang sepanjang tahun 2016. Laba bersih perusahaan tertekan $32,4 \%$ jika dibandingkan dengan laba bersih tahun 2015. Laba bersih yang tercatat sebesar Rp 313,45 miliar pada tahun 2016, lebih rendah dari tahun sebelumnya sebesar Rp 463,68 miliar. Laba tersebut terkuras karena tumbuhnya beban pokok pendapatan hingga $18 \%$ dari $\mathrm{Rp} \mathrm{8,41}$ triliun menjadi Rp 9,94 triliun dan diikuti peningkatan jumlah beban usaha menjadi Rp 455,97 miliar atau naik 15,29\% dari Rp 395,49 miliar (cnnindonesia.com/ekonomi diakses 17 Februari 2017). Selanjutnya PT Modernland Realty Tbk (MDLN) pada tahun 2013 yang tidak bisa menjamin laba yang persisten karna turun pada tahun 2014 sebesar 70,98\% atau menjadi Rp 711,26 miliar dari laba bersih sebesar Rp 2,45 triliun di tahun 2013 (Sari, 2016).

Laporan laba rugi suatu perusahaan dapat saja memberikan gambaran bahwa perusahaan tersebut mendapatkan keuntungan yang tinggi, Namun laporan arus kas bisa saja memperlihatkan bahwa perusahaan sebenarnya kekurangan uang kas. Laporan arus kas melaporkan penerimaan dan pengeluaran kas entitas selama periode tertentu dari mana kas datang dan bagaimana dibelanjakannya. Perusahaan dituntut agar mampu mengelola dana yang ada untuk membiayai segala kegiatannya dan harus hati-hati dalam menangani masalah keuangan, khususnya dalam pengelolaan sumber dan penggunaan kas yang baik sangat diperlukan, karena dapat memberikan informasi tentang 


\section{JURNAL TAMBORA}

Vol. 3 No. 1 Februari 2019

kemampuan perusahaan dalam mendapatkan laba serta mengetahui kondisi likuiditas perusahaan di masa yang akan datang (Hayati, 2011). Khususnya arus kas kegiatan operasi yang pada konsepnya memiliki komponen-komponen dalam bentuk jangka pendek seperti aset lancar dan hutang jangka pendek sama halnya dengan konsep perhitungan laba yaitu secara periodik.

Faktor lain yang mempengaruhi persistensi laba yaitu siklus operasi. Berkaitan pula dengan persistensi laba dalam perusahaan yang dilihat dari variabel siklus operasi yaitu seberapa lama persediaan dibuat, kemudian dijual, dan selanjutnya pengumpulan piutang menjadi kas, sehingga siklus operasi berhubungan langsung dengan laba perusahaan (Armaidah, 2016).

Ukuran perusahaan menjadi salah satu faktor yg mempengaruhi persistensi laba. Menurut Romasari (2013), ukuran perusahaan dapat menentukan baik tidaknya kinerja perusahaan. Hal ini juga dikemukan oleh Dewi dan Putri (2015) bahwa semakin besarnya suatu perusahaan, maka diharapkan pula pertumbuhan laba yang tinggi. Penelitian ini menggunakan salah satu instrumen sebagai salah satu alat ukur ukuran perusahan, yaitu: total asset. Pemilihan total aset karena besaran total aset mewakili tersedianya sumber daya untuk kegiatan perusahaan dimana kegiatan tersebut cenderung digunakan untuk memperoleh laba. Oleh karena itu, secara tidak langsung ukuran perusahaan dapat digunakan untuk menentukan kemampuan suatu perusahaan dalam mengendalikan serta menghasilkan laba (Nuraini, 2014). Pandangan tersebut sejalan dengan penelitian Dewi dan Putri (2015) menemukan bahwa ukuran perusahaan berpengaruh positif pada persistensi laba.

Selain faktor-faktor diatas yang dapat mempengaruhi persitensi laba adalah tingkat hutang. Hutang merupakan salah satu cara untuk mendapat tambahan pendanaan dari pihak eksternal, dengan konsekuensi perusahaan akan menjalin ikatan kontrak dengan kreditur. Ikatan kontrak berisi mengenai janji pembayaran utang dengan nominal dan batasan waktu yang ditentukan. Pada satu sisi, hutang akan menambah modal dari perusahaan namun di sisi yang lain, utang menimbulkan konsekuensi perusahaan untuk harus selalu membayar bunga dan pokok pada saat jatuh tempo tanpa memperhatikan kondisi keuangan perusahaan. Tetapi pecking order theory menyatakan bahwa menerbitkan hutang merupakan sumber pendanaan yang paling aman dibanding dengan cara yang lain (Sukman, 2017).

Pengambilan objek penelitian pada perusahaan jasa sub sektor konstruksi dan bangunan yang terdaftar Bursa Efek Indonesia (BEI) karena pada tahun 2017 dalam pemerintah presiden Joko Widodo terus menggenjot pembangunan infastruktur sehingga peneliti tertarik untuk mengetahui pengaruh arus kegiatan operasi, siklus operasi, ukuran perusaan dan tingkat hutang dalam mempemgaruhi persistensi laba pada perusahaan jasa sub sektor konstrusi dan bangunan.

Penelitian yang dilakukan oleh Azzahra, dkk (2016) menunjukkan aliran kas operasi berpengaruh terhadap persistensi laba secara parsial. Menurut Septavita (2016) arus kas operasi, tingkat hutang dan ukuan perusahaan berpengaruh signifikan terhadap persistensi laba. Namun berbeda dengan penelitian Chowijaya, dkk (2014) bahwa arus kas operasi tidak memilki pengaruh secara individual terhadap persistensi laba. Hasil penelitian Armaidah (2016) bahwa siklus operasi dan leverage tidak berpengaruh terhadap persistensi laba sedangkan volatilitas arus kas berpengaruh terhadap persistensi laba.

Berdasarkan uraian masalah dan perbedaan hasil penelitian sebelumnya. Maka peneliti tertarik untuk meneliti pengaruh arus kas kegiatan operasi, siklus operasi, ukuran perusahaan, dan tingkat hutang terhadap persistensi lada pada perusahaan jasa sub sektor kontruksi dan bangunan yang terdaftar di Bursa Efek Indonesia (BEI) periode 2013-2016.

Rumusan Masalah: 1) Bagaimana pengaruh arus kas kegiatan operasi, siklus operasi, ukuran perusahaan, dan tingkat hutang secara signifikan individual terhadap persistensi laba ? 2) Bagaimana pengaruh arus kas kegiatan operasi, siklus operasi, ukuran perusahaan, dan tingkat hutang secara simultan terhadap persistensi laba?

Tujuan Penelitian: 1) Untuk mengetahui pengaruh arus kas kegiatan operasi, siklus operasi, ukuran perusahaan, dan tingkat hutang secara signifikan individual terhadap persistensi laba ? 2) Untuk mengetahui pengaruh arus kas kegiatan operasi, siklus operasi, ukuran perusahaan, dan tingkat hutang secara signifikansi simultan terhadap persistensi laba?.

\section{LANDASAN TEORI}

1. Persistensi Laba

Persistensi laba merupakan suatu ukuran yang menjelaskan kemampuan perusahaan untuk mempertahankan jumlah laba yang diperoleh saat ini sampai masa mendatang (Sulastri, 2010). Laba yang persisten adalah laba yang menunjukkan keberlanjutan laba dimasa yang akan datang yang ditentukan oleh komponen akrual dan aliran kas (Chowijaya, dkk. 2014). Menurut Saputera, dkk. (2017) persistensi laba merupakan salah satu komponen dari kualitas laba. Penman. (2003) pengertian persistensi laba merupakan laba yang memiliki kemampuan sebagai indikator laba periode mendatang (future earning) yang dihasilkan oleh perusahaan secara berulang-ulang (repetitive) dalam jangka panjang (sustainable).

\section{Arus Kas Operasi}




\section{Vol. 3 No. 1 Februari 2019}

Laporan arus kas merupakan laporan yang menyajikan informasi tentang arus kas masuk dan arus kas keluar, dan setara kas suatu entitas untuk suatu periode tertentu (Martani, dkk. (2012;145).

Aliran kas dari aktivitas operasi merupakan aliran kas yang diperoleh dari kegiatan usaha perusahaan. Kegiatan utama perusahaan adalah menghasilkan barang atau jasa dan menjualnya. Kegiatan ini mencakupi kegiatan penerimaan kas, misalnya penjualan barang atau jasa tunai dan penerimaan piutang. Aliran kas operasi (PTCF) sebagai proksi komponen laba permanen merupakan aliran kas masuk dan kas keluar dari aktivitas operasi sebelum pajak (pretax cash flow) yang dihitung sebagai total aliran kas operasi dikurangi aliran kas dari pos luar biasa dan ditambah pajak penghasilan (Septavita, 2016). Kieso et al. (2002:242) dalam Kusumaningtyas (2016) menyatakan bahwa arus kas aktivitas operasi diperoleh dari aktivitas penghasil utama pendapatan perusahaan. Jika kas bersih yang disediakan oleh aktivitas operasi tinggi, berarti perusahaan mampu menghasilkan kas yang mencukupi secara internal dari operasi untuk membayar kewajiban tanpa harus meminjam dari luar. Sebaliknya, jika jumlah kas bersih yang dihasilkan oleh aktivitas operasi rendah atau negatif, berarti perusahaan tidak mampu menghasilkan kas yang memadai secara internal dari opersinya. Sumber kas ini umumnya dianggap sebagai ukuran terbaik dari kemampuan perusahaan dalam memperoleh dana yang cukup guna terus melanjutkan usahanya.

Arus kas dari kegiatan operasi dapat disajikan dengan dua metode, yaitu sebagai berikut (Martani, dkk. $(2012 ; 148)$ :

a. Metode langsung, yang menyajikan kelompok utama penerimaan kas bruto (gross) dan pembayaran kas bruto, atau

b. Metode tidak langsung, dimulai dengan laba atau rugi periode berjalan menyesesuaikan laba rugi tersebut dengan traksaksi nonkas, akrual, dan tangguhan dari pos yang penghasilan atau pengeluaran dalam aktivitas investasi dan pendanaan.

Ikatan Akuntan Indonesia dalam PSAK No. 2 (1995:2.7) untuk perusahaan dianjurkan menggunakan metode langsung karena menghasilkan informasi yang berguna dalam mengestimasi arus kas masa depan yang tidak dapat dihasilkan oleh metode tidak langsung. Metode langsung dalam penyusunannya membutuhkan waktu yang lama dan lebih sulit dibandingkan dengan metode tidak langsung yang lebih muda dan sederhana. Menurut Irfan (2012) bahwa adapun arus kas yang masuk dan keluar dari kegiatan operasi mencakup antara lain:

a. Arus kas yang masuk dari penjualan barang dan jasa, pendapatan dividen, pendapatan bunga, dan penerimaan operasi lainnya. b. Arus kas yang keluar untuk pembayaran kepada pemasok barang dan jasa, pembayaran kepada karyawan, bunga yang dibayarkan atas hutang perusahaan, pembayaran pajak, dan pengeluaran operasi lainnya.

Arus kas operasi di catat pada bagian awal laporan arus kas karena arus kas operasi merupakan sumber kas terbesar dan sangat penting untuk sebagian besar perusahaan. Kegagalan operasi perusahaan untuk menghasilkan arus kas masuk yang besar untuk suatu periode yang panjang dapat merupakan tanda adanya kesulitan pada perusahaan (Hayati, 2011). Jadi dapat disimpulkan arus kas operasi adalah kumpulan aliran kas yang bersumber dari kegiatatan utama perusahan yaitu berupa kas dari penjualan barang atau jasa dan menerima pengembalian piutang.

\section{Siklus Operasi}

Siklus operasi adalah periode waktu rata-rata antara pembelian persediaan dengan pendapatan kas yang nantinya akan diterima penjual. Atau rangkaian seluruh transaksi dimana suatu bisnis menghasilkan penerimaannya dan penerimaan kasnya dari pelanggan. Siklus operasi suatu perusahaan terdiri dari transaksi-transaksi berikut:(a) pembelian barang,(b) penjualan barang, dan (c) pengumpulan piutang dari pelanggan. Siklus operasi bersinggungan langsung dengan laba perusahaan, hal ini dikarenakan ada faktor penjualan di dalam siklus operasi (Fanani, 2010). Menurut Purwanti (2010) siklus operasi yang hubungan dengan laba karena adanya faktor penjualan. Laba tersebut nantinya akan digunakan untuk memprediksi aliran kas dimasa yang akan datang. Maka dari itu, laba yang digunakan untuk memprediksi aliran kas dimasa yang akan datang, harus benar-benar laba yang berkualitas. Dimana laba yang berkualitas sendiri tergantung pada siklus operasi perusahaan itu sendiri.

4. Ukuran Perusahaan

Ukuran perusahaan merupakan nilai yang menunjukkan besar kecilnya perusahaan (Taures, 2011). Penelitian ini menggunakan ukuran perusahaan diukur berdasarkan total aset yang dimiliki oleh perusahaan. IFRS (2015) mendefinisikan aset sebagai sumber daya yang dikuasai oleh entitas sebagai akibat dari peristiwa masa lalu dan dari manfaat ekonomi masa depan diharapkan akan diperoleh. Total aset terdiri atas aset lancar dan aset tidak lancar. Aset lancar terdiri atas kas, piutang, persediaan, investasi jangka pendek, dan biaya dibayar di muka. Sedangkan, aset tidak lancar terdiri atas investasi jangka panjang, aset tetap, aset tak berwujud, dan aset lain yang bersifat tidak lancar.

Samisi dan Ardiana (2013) mengemukakan bahwa ukuran perusahaan dapat mempengaruhi nilai perusahaan karena semakin besar ukuran perusahaan maka akan semakin mudah perusahaan tersebut mendapatkan dana baik dari internal 
JURNAL TAMBORA

Vol. 3 No. 1 Februari 2019

ataupun eksternal perusahaan. Perusahaan yang besar cenderung memiliki sumber permodalan yang lebih banyak dan memiliki kemungkinan untuk bangkrut lebih kecil, sehingga mampu untuk memenuhi kewajiban finansialnya.

\section{Tingkat Hutang}

Hutang dibagi menjadi dua jenis yaitu hutang jangka pendek dan hutang jangka panjang dan hutang jangka pendek. Hutang jangka pendek merupakan sumber pembiayaan yang jatuh tempo dalam kurun waktu satu tahun atau kurang dari satu tahun, biasanya dialokasikan sebagai penambahan modal kerja pada siklus operasi normal. Sedangkan hutang jangka panjang merupakan sumber pembiayaan yang dialokasikan untuk ekspansi atau perluasan usaha karena perusahaan membutuhkan modal yang cukup besar dan memerlukan waktu yang cukup lama untuk mengembalikan modal dari ekspansi (Setiana. 2012 dalam Nuraini, 2014).

Tingkat hutang didefinisikan sebagai rasio total hutang dibandingkan total aset. Kebijakan utang merupakan salah satu alternatif pendanaan perusahaan selain menjual saham di pasar modal (modal ekuitas). Karakteristik modal ekuitas mencakup pengembaliannya yang tidak pasti dan tidak tentu serta tidak adanya pola pembayaran kembali. Berbeda dengan modal ekuitas, baik modal utang jangka pendek maupun jangka panjang harus dibayarkan kembali pada waktu tertentu tanpa memerhatikan kondisi keuangan perusahaan (Nuraini, 2014). Tingkat hutang mencerminkan kewajiban perusahaan yang harus dibayarkan kepada pihak ketiga saat jatuh tempo tanpa mempertimbangkan kondisi perusahaan. Semakin tinggi tingkat hutang, maka akan semakin besar usaha manajemen untuk memperlihatkan kinerja perusahaan yang baik, ditunjukkan melalui tingginya persistensi laba perusahaan (Kusuma dan Sadjiarto. 2014).

Tingkat hutang merupakan besaran hutang yang dimiliki oleh perusahaan. Besarnya tingkat hutang perusahaan akan menyebabkan perusahaan meningkatkan persistensi laba dengan tujuan untuk mempertahankan kinerja yang baik di mata investor dan kreditor. Dengan kinerja yang baik tersebut maka diharapkan kreditor tetap memiliki kepercayaan terhadap perusahaan, dan mudah mengucurkan dana, sehingga perusahaan akan memperoleh kemudahan dalam proses pembayaran (Fanani, 2010).

\section{METODOLOGI}

Populasi dalam penelitian ini yaitu perusahaan jasa sub sektor konstruksi dan bangunan yang terdaftar di BEI periode 2013-2016, berjumlah 12 perusahaan. Teknik pengambilan sampel menggunakan purposive sampling sehingga diperoleh 9 perusahaan sampel. Penelitian menggunakan data skunder yaitu laporan keuangan perusahaan yang telah diaudit.

\section{Definisi Operasional Variabel Dan Pengukuran}

\section{Persistensi Laba}

Menurut perhitungan yang dianut oleh Azzahra (2016) bahwa menghitung persistensi laba dengan perubahan laba sebelum pajak tahun yang terdiri dari laba sebelum pajak tahun ini dikurangi laba sebelum pajak tahun sebelumnya dibagi dengan total asset.

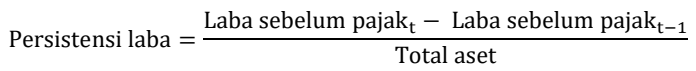

\section{Arus Kas Kegiatan Operasi}

Operasi menurut PSAK No. 2 metode langsung (paragraph 18(a)) adalah sebagai berikut:

$\mathrm{AKO}=$ Total arus kas kegiatan operasi

Siklus operasi

Fanani (2010) diukur dengan menggunakan rumus:

Siklus operasi $=\frac{\text { piutang }_{t}+\text { piutang }_{t-1 / 2}}{\text { penjualan }_{360}}+$
$\frac{\text { persediaan }_{t}+\text { persediaan }_{t-1 / 2}}{\text { harga pokok penjualan } / 360}$

\section{Ukuran perusahaan}

Adapun rumus yang dipakai dalam mengukur ukuran perusahaan yang digunakan oleh Nuraini (2014), adalah

Ukuran perusahaan $=\log$ (total aset)

\section{Tingkat hutang}

Menurut Fahmi (2013;64) tingkat hutang diperoleh dari perbandingan total hutang dengan total asset.

$$
\text { Tingkat hutang }=\frac{\text { Total hutang }}{\text { Total aset }}
$$

Penelitian diregresi menggunakan data panel yaitu gabungan data time series dan data cross section. Selanjutnya diuji menggunakan bantuan softwere STATA 11. Penelitian menggunakan regresi Polled Least Squares.

\section{HASIL DAN PEMBAHASAN}

Analisis deskriptif bertujuan untuk memberikan informasi tentang data penelitian secara umum kepada pembaca. Dalam penelitian ini pengukuran statistik deskriptif berupa nilai minimum (min), nilai maksimum (max), nilai rata rata (mean), dan standar deviasi. Berikut tabel hasil analisis deskriptif. 
Tabel 4.1 Statistik deskriptif

\begin{tabular}{rrrrrr}
\hline $\begin{array}{c}\text { Varia } \\
\text { ble }\end{array}$ & $\begin{array}{c}\text { Ob } \\
\text { s }\end{array}$ & \multicolumn{1}{c}{ Mean } & Std. Dev. & \multicolumn{1}{l}{ Min } & \multicolumn{1}{l}{ Max } \\
\hline Kode & 36 & 5 & 2.618615 & 1 & 9 \\
Tahun & 36 & 2014.5 & 1.133893 & 2013 & 2016 \\
& & $-180 \mathrm{x}$ & $140 \mathrm{x}$ & $-776 \mathrm{x}$ & $987 \mathrm{x}$ \\
Ako & 36 & $10^{9}$ & $10^{10}$ & $10^{10}$ & $10^{9}$ \\
So & 36 & 208.9244 & 100.6875 & 84.07 & 552.9 \\
& & & 0.537570 & & \\
Size & 36 & 12.72889 & 1 & 11.17 & 13.79 \\
& & & 0.124395 & & \\
Th & 36 & 0.63 & 7 & 0.46 & 0.84 \\
& & - & & & \\
Pl & 36 & 0.006666 & 0.052263 & & \\
\hline
\end{tabular}

Sumber : Output STATA 11 yang diolah tahun 2018

Pertama yaitu uji Chow. Hasil uji dengan melihat nilai prob $>\mathrm{F}$ yang paling bawah dari hasil output fixed effect, dengan kriteria penolakan Ho jika nilai prob $>F$ lebih kecil dari $\alpha$.

Tabel 4.2 Chow test dan lagrange Multiplier test

\begin{tabular}{|c|c|c|}
\hline Uji & Hasil & Keterangan \\
\hline Chow Test & $\begin{array}{l}\text { Prob }>F= \\
0,5116\end{array}$ & $\begin{array}{l}\text { Ho (pooled least } \\
\text { squares), diterima } \\
\text { Ha (fixed effect) }\end{array}$ \\
\hline $\begin{array}{l}\text { Lagrange } \\
\text { Multiplier } \\
\text { Test }\end{array}$ & $\begin{array}{l}\text { Prob }>\text { chi } 2= \\
0,2989\end{array}$ & $\begin{array}{l}\text { Ho (pooled least } \\
\text { squares), diterima } \\
\text { Ha (randown effect) }\end{array}$ \\
\hline
\end{tabular}

Dari hasil output fixed effect menunjukkan hasil nilai Prob $>\mathrm{F}=0.5116(\alpha=5 \%)$ maka hasil uji chow menyatakan Ho diterima dan Ha ditolak yang berarti model yang digunakan yaitu pooled least squares.

Pengujian selanjutnya yaitu lagrange multiplier test karena pada uji chow menunjukkan Ho diterima, maka pooled least squares akan dibandingkan dengan model randown effect untuk dipilih model estimasi yang baik digunakan dalam penelitian ini, dengan kriteria penolakan Ho jika nilai Prob $>$ Chi2 lebih kecil dari $\alpha$.

Dari hasil uji lagrange multiplier (LM) menunjukkan nilai Prob $>$ chi2 $=0.2989$ lebih besar dari $(\alpha=0.05)$ berarti Ho diterima dan Ha ditolak maka model regresi yang digunakan yaitu pooled least squares.

Maka model regresi yang baik digunakan dalam penelitian ini adalah pooled least squares karena telah didukung oleh 2 uji yaitu chow test dan lagrange multiplier test sehingga houseman test tidak perlu dilakukan.

\section{Pengujian asumsi klasik}

\section{Multikolinearitas}

Untuk mengetahui ada tidaknya multikolinearitas dapat dilihat dari nilai mean VIF, jika nilai mean VIF lebih besar dari 10 maka terjadi multikolinearitas.

Tabel 4.3 Hasil multikolinearitas

\begin{tabular}{|lll|}
\hline Variable & VIF & 1/VIF \\
Th & 1.57 & 0.636811 \\
Size & 1.56 & 0.640865 \\
So & 1.28 & 0.77827 \\
Ako & 1.13 & 0.888419 \\
Mean VIF & 1.39 & \\
Variable & VIF & $1 /$ VIF \\
Th & 1.57 & 0.636811 \\
Size & 1.56 & 0.640865 \\
So & 1.28 & 0.77827 \\
Ako & 1.13 & 0.888419 \\
Mean VIF & 1.39 & \\
Variable & VIF & $1 /$ VIF \\
Th & 1.57 & 0.636811 \\
Size & 1.56 & 0.640865 \\
So & 1.28 & 0.77827 \\
Ako & 1.13 & 0.888419 \\
Mean VIF & 1.39 & \\
\hline Sumber : Output STATA 11 yang diolah tahun 2018
\end{tabular}

Hasil uji multikolinearitas yang terdapat pada Tabel 4.5 menunjukkan nilai mean VIF kurang dari 10 yaitu sebesar 1,39 , sehingga dapat disimpulkan bahwa tidak terjadi multikolinearitas sehingga data layak untuk dijadikan penelitian.

\section{Heterokedastisitas dan autokorelasi}

Tabel 4.4 hasil heterokedastisitas dan autokorelasi

\begin{tabular}{lll}
\hline \multicolumn{1}{c}{ Uji } & \multicolumn{1}{c}{ Hasil } & \multicolumn{1}{c}{ Keterangan } \\
\hline $\begin{array}{l}\text { Heteroked } \\
\text { astisitas }\end{array}$ & $\begin{array}{l}\text { Prob>chi2 } \\
=0.0000\end{array}$ & $\begin{array}{l}\text { Ho: (Homokedastisitas) } \\
\text { Ha:(Heterokedastisitas),diterima }\end{array}$ \\
$\begin{array}{lll}\text { Autikorela } \\
\text { si }\end{array}$ & $\begin{array}{l}\text { Prob>chi2 } \\
=0.0195\end{array}$ & $\begin{array}{l}\text { Ho: (No autokorelasi) } \\
\text { Ha:(Autokorelasi), diterima }\end{array}$ \\
\hline \multicolumn{1}{c}{ Uji } & heteroskedastisitas bertujuan untuk
\end{tabular}
mengetahui apakah dalam suatu persamaan regresi terjadi ketidaksamaan varians antara residual. Dalam uji ini diharapkan tidak terjadi heteroskedastisitas.

Berdasarkan tebel diatas, dapat lihat bahwa nilai Prob $>$ chi $2=0.0000$ lebih kecil dari $(\alpha=0.05)$. Oleh karena itu diputuskan Ha diterima dan dapat dikatakan bahwa terjadi heteroskedastisitas.

Uji autokorelasi bertujuan umtuk mengetahui apakah ada korelasi antara anggota serangkaian data observasi berdasarkan waktu (time-series) atau ruang (cross section). Harapan dari uji autokorelasi yaitu tidak terjadinya autokorelasi, dengan kriteria penolakan Ho apabila Prob $>$ chi2 lebih lecil dari $\alpha$.

Dari hasil uji autokorelasi pada tabel 4.7 dapat disimpulkan bahawa terjadi autokorelasi dimana nilai Prob $>\mathrm{F}=0.0195$ lebih kecil dari 0.05 yang berarti Ho diterima dan Ha ditolak. 


\section{Hasil Persamaan Regresi}

Setelah dilakukan pengujian asumsi klasik dan dapat diketahui data tidak BLUE (Best Linear Unbiased Estimator) maka data selanjutnya diuji dengan Robust untuk dilayakkan.

Table 4.5 Hasil robust

\begin{tabular}{|c|c|c|c|c|}
\hline \multirow[t]{2}{*}{$\begin{array}{l}\text { Prob }>\mathrm{F}= \\
\mathrm{R}-\text { squared }=\end{array}$} & & $\begin{array}{l}000 \\
537\end{array}$ & & \multirow[b]{2}{*}{$\mathrm{P}>\mathrm{It}$} \\
\hline & $\mathrm{pl}$ & Coef. & $\mathrm{t}$ & \\
\hline & ako & $148 \times 10^{-19}$ & 0.01 & 0.993 \\
\hline & so & 0.0001577 & -1.28 & 0.212 \\
\hline & size & 0.0065816 & 0.41 & 0.682 \\
\hline & th & 0.1621803 & 2.06 & 0.047 \\
\hline & con & -0.1596614 & -0.73 & 0.470 \\
\hline
\end{tabular}

$$
\begin{aligned}
\mathrm{PL}= & -0.1596614+0.000000000000000000148_{\mathrm{AKO}} \\
& -0.0001577_{\mathrm{SO}}+0.0065816_{\mathrm{SIZE}}+ \\
& 0.1621803_{\mathrm{TH}}+\varepsilon
\end{aligned}
$$

\section{Pengujian Hipotesis}

\section{Uji Signifikansi Individual (uji t)}

Uji signifikan individual menunjukkan seberapa jauh pengaruh variabel independen terhadap variabel dependen secara individual. Pengujian dapat dilakukan dengan melihat perbandingan nilai prob $>\mathrm{t}$ dengan $\alpha$. Apabila nilai prob $>\mathrm{t}$ lebih kecil dari a (0.05) maka Ha diterima dan Ho ditolak begitu juga sebaliknya. Pada tabel 4.7 dapat disimpulkan bahwa:

\section{Arus Kas Kegiatan Operasi terhadap persistensi laba}

Hipotesis arus kas kegiatan operasi diajukan sebagai berikut :

Ho: Tidak terdapat pengaruh yang signifikan Arus kas kegiatan operasi terhadap persistensi laba.

Ha : Terdapat pengaruh yang signifikan Arus kas kegiatan operasi terhadap persistensi laba.

Berdasarkan tabel 4.8 bahwa nilai prob $>t$ untuk arus kas kegiatan operasi (AKO) sebesar 0.063 lebih besar dari $\alpha(0.05)$, maka Ho diterima dan $\mathrm{Ha}$ ditolak sehingga arus kas kegiatan operasi (AKO) secara individual tidak terdapat pengaruh yang signifikan terhadap persistensi laba pada perusahaan jasa sub sektor konstruksi dan bangunan yang daftar di BEI periode 2013-2016.

\section{Siklus Operasi terhadap persistensi laba \\ Hipotesis siklus operasi diajukan sebagai} berikut :

Ho: Tidak terdapat pengaruh yang signifikan siklus operasi terhadap persistensi laba.
Ha: Terdapat pengaruh yang signifikan siklus operasi terhadap persistensi laba.

Nilai prob $>t$ untuk siklus operasi (SO) sebesar 0.212 lebih besar dari $\alpha(0.05)$, maka Ho diterima dan Ha ditolak sehingga siklus operasi (SO) secara individual tidak terdapat pengaruh yang signifikan terhadap persistensi laba pada perusahaan jasa sub sektor konstruksi dan bangunan yang daftar di BEI periode 2013-2016.

\section{Ukuran Perusahaan terhadap persistensi laba}

Hipotesis ukuran perusahaan diajukan sebagai berikut :

Ho : Tidak terdapat pengaruh yang signifikan ukuran perusahan terhadap persistensi laba.

Ha : Terdapat pengaruh yang signifikan ukuran perusahan terhadap persistensi laba.

Nilai prob $>t$ untuk ukuran perusahaan (SIZE) sebesar 0.682 lebih besar dari $\alpha(0.05)$, maka Ho diterima dan $\mathrm{Ha}$ ditolak sehingga ukuran perusahaan (SIZE) secara individual tidak terdapat pengaruh yang signifikan terhadap persistensi laba pada perusahaan jasa sub sektor konstruksi dan bangunan yang daftar di BEI periode 2013-2016.

\section{Tingkat hutang terhadap persistensi laba}

Hipotesis tingkat hutang diajukan sebagai berikut :

Ho :Tidak terdapat pengaruh yang signifikan tingkat hutang terhadap persistensi laba.

$\mathrm{Ha}$ : Terdapat pengaruh yang signifikan tingkat hutang terhadap persistensi laba.

Nilai prob $>t$ untuk tingkat hutang (TH) sebesar 0.047 lebih kecil dari $\alpha(0.05)$, maka Ha diterima dan Ho ditolak sehingga tingkat hutang $(\mathrm{TH})$ secara individual terdapat pengaruh yang signifikan terhadap persistensi laba pada perusahaan jasa sub sektor konstruksi dan bangunan yang daftar di BEI periode 2013-2016.

\section{Uji signifikansi Simultan (uji statistik F)}

Hipotesis untuk arus kas kegiatan operasi, siklus operasi, ukuran perusahaan, dan tingkat hutang adalah :

Ho : Arus Kas Kegiatan Operasi (AKO), Siklus Operasi (SO), Ukuran Perusahaan (SIZE) dan Tingkat Hutang $(\mathrm{TH})$ tidak terdapat pengaruh yang signifikan terhadap persistensi laba (PL)

Ha : Arus Kas Kegiatan Operasi (AKO), Siklus Operasi (SO), Ukuran Perusahaan (SIZE) dan Tingkat Hutang $(\mathrm{TH})$ terdapat pengaruh yang signifikan terhadap persistensi laba (PL)

Berdasarkan nilai Prob $>\mathrm{F}$ yang ditunjukkan oleh tabel 4.5 sebesar 0.0000 jauh berada dibawah 0.05 berarti Ho ditolak dan Ha diterima, maka arus kas kegiatan operasi, arus kas akrual, ukuran perusahaan, dan tingkat hutang secara bersamasama berpengaruh terhadap persistensi laba pada 
JURNAL TAMBORA

Vol. 3 No. 1 Februari 2019

perusahaan jasa sub sektor konstruksi dan bangunan yang terdaftar di BEI periode 2013-2016.

\section{Koefisien determinasi $\left(\mathbf{R}^{2}\right)$}

Berdasarkan tabel 4.5 menunjukkan hasil Rsquared sebesar 0.1537 . Hal ini menunjukkan arus kas kegiatan operasi, siklus operasi, ukuran perusahaan, dan tingkat hutang dapat menjelaskan persistensi laba pada perusahaan jasa sub sektor konstruksi dan bangunan yang terdaftar di BEI periode 2013-2016 sebesar 15,37\% dan $84.63 \%$ dipengaruhi oleh variabel lain yang tidak dilibatkan dalam penelitian ini.

\section{Pembahasan Hasil Estimasi dan Interpretasi}

Setelah dilakukan estimasi model dan pengujian hipotesis maka selanjutnya hasil ditelaah secara lebih rinci untuk mengetahui pengaruh arus kas kegiatan operasi, siklus operasi, ukuran perusahaan dan tingkat hutang terhadap persistensi laba pada perusahaan jasa sub sektor konstruksi dan banguan yang terdaftar di Bursa Efek Indonesia periode 2013-2016. Hasil pengujian masing-masing variable sebagai berikut :

\section{Pengaruh Arus Kas Kegiatan Operasi terhadap Persistensi Laba}

ilai prob $>t$ untuk arus kas kegiatan operasi (AKO) sebesar 0.063 dan nilai koefisiennya sebesar 0.0000000000000000148. nilai koefisen yang positif dan tidak signifikan tersebut berarti tidak terdapat pengaruh yang signifikan arus kas kegiatan operasi terhadap persistensi laba pada perusahaan jasa sub sektor konstruksi dan bangunan yang daftar di BEI periode 2013-2016 atau kenaikan maupun penurunan nilai arus kas kegiatan operasi tidak mengakibatkan kenaikan atau penurunan nilai dari persistensi laba. Hasil penelitian ini sejalan dengan penelitian Chowijaya (2014) bahwa arus kas operasi tidak memiliki pengaruh secara individual terhadap persistensi laba pada industri yang tergabung di indeks LQ-45. Namun, berbeda dengan penelitian Septavita (2016) bahwa arus kas operasi mempunyai pengaruh yang signifikan terhadap persistensi laba pada perusahaan manufaktur yang terdaftar di BEI tahun 2011-2013.

Arus kas operasi adalah kumpulan aliran kas yang bersumber dari kegiatatan utama perusahan yaitu berupa kas dari penjualan barang atau jasa dan menerima pengembalian piutang. Sebagaimana yang dijelaskan oleh Septavita (2016) bahwa semakin tinggi aliran kas operasi terhadap laba maka akan semakin tinggi pula kualitas laba atau persistensi laba tersebut. Namun, yang terjadi pada perusahaan jasa sub sektor konstruksi dan bangunan yaitu rendahnya aliran kas kegiatan operasi sehingga menjadi penyebab aliran kas kegiatan operasi tidak berpengaruh terhadap persistensi laba. Pada tabel 4.1 dapat dilihat bahwa nilai rata-rata arus kas kegiatan operasi berada pada minus 180000000000 . Hal ini mengindikasikan bahwa aliran kas operasi perusahaan sampel mengalami lebih sering melakukan pengeluaran daripada pemasukkan, karena perusahaan jasa pendapatannya diakui dengan dua metode yaitu metode kontrak selesai dan metode persentase penyelesaian. Jadi, perusahaan konstruksi dalam mengerjakan suatu proyek akan dikerjakan terlebih dahulu dan setelah itu baru pencairan dana dalam rentang waktu tertentu sesuai perjanjian dengan pemberi kerja.

\section{Pengaruh Siklus Operasi terhadap Persistensi Laba}

Nilai prob $>t$ untuk siklus operasi (SO) sebesar 0.212 lebih besar dari $\alpha$ (0.05) dengan nilai koefisien -0.0001577 . Nilai koefisien yang negatif dan tidak signifikan tersebut berarti siklus operasi (SO) secara individual tidak terdapat pengaruh yang signifikan terhadap persistensi laba pada perusahaan jasa sub sektor konstruksi dan bangunan yang daftar di BEI periode 2013-2016 atau kenaikan maupun penurunan nilai siklus operasi tidak mengakibatkan kenaikan atau penurunan nilai dari persistensi laba. Menurut Susilo dan Anggraeni (2015), hal ini menunjukkan bahwa lama tidaknya siklus operasi, tidak mempengaruhi modal kerja perusahaan dan realisasi kas yang lebih lama sehingga kinerja perusahaan juga tidak terpengaruh. Hasil penelitian ini sejalan dengan penelitian Armaidah (2016) bahwa siklus operasi tidak berpengaruh terhadap persistensi laba.

Tidak berpengaruhnya siklus operasi terhadap persistensi laba karena perusahaan sampel yang merupakan perusahaan jasa sub sektor konstruksi dan bangunan pendapatannya tergantung pada proyek. Misalnya suatu proyek yang dikerjakan lebih dari satu periode, sehingga menyebabkan pencairan dana dalam waktu yang lama, karena pencairan yang lama perusahaan tidak menerima kas yang seharusnya merupakan laba tahun berjalan yang dapat mencerminkan laba selanjutnya. Pada konsepnya perusahaan konstruksi mengakui pendapatan dengan dua metode yaitu metode kontrak selesai dan metode persentase penyelesaian. Jadi, apabila menggunakan metode kontrak selesai maka pendapatan diakui setelah pekerjaan selesai 100\%. Sedangkan metode persentase penyelesaian pendapatan diakui pada setiap periode berdasarkan $\%$ penyelesaian pekerjaan periode tersebut.

\section{Pengaruh Ukuran Perusahaan terhadap Persistensi Laba}

Nilai prob $>t$ untuk ukuran perusahaan (SIZE) sebesar 0.682 lebih besar dari $\alpha(0.05)$ dengan koefisien sebesar 0.0065816. nilai koefisien bertanda positif dan tidak signifikan tersebut menunjukkan ukuran perusahaan (SIZE) secara individual tidak terdapat pengaruh yang signifikan terhadap persistensi laba pada perusahaan jasa sub 
Vol. 3 No. 1 Februari 2019

sektor konstruksi dan bangunan yang daftar di BEI periode 2013-2016 atau kenaikan maupun penurunan nilai ukuran perusahaan tidak mengakibatkan kenaikan atau penurunan nilai dari persistensi laba. Hasil penelitian ini konsisten dengan penelitian Nurochman dan Solikhah (2015) bahwa ukuran perusahaan tidak terdapat perngaruh yang signifikan terhadap persistensi laba. Namun berbeda dengan penelitian Putri dan Dewi (2015) bahwa ukuran perusahaan berpengaruh poritif terhadap persistensi laba.

Hasil penelitian didukung oleh Romasari (2013), menyatakan bahwa investor menganggap perusahaan yang besar belum tentu memberikan keuntungan yang besar. Efeknya, ukuran perusahaan tidak selalu dapat mencerminkan keadaan yang sebenarnya dari persistensi laba suatu perusahaan. Oleh karena itu, investor lebih memilih melihat kondisi pasar perusahaan secara umum daripada melihat total asetnya. Jadi, ukuran perusahaan tidak menjamin bahwa semakin besar ukuran suatu perusahaan maka persistensi labanya akan semakin baik. Dalam teori stewardship manajer akan berperilaku sesuai kepentingan bersama. Sehingga besar/kecilnya suatu perusahaan tidak akan menpengaruhi penurunan/kenaikan laba perusahaan (Nurochman dan Solikhah, 2015)

\section{Pengaruh Tingkat Hutang terhadap Persistensi Laba}

Nilai prob $>$ t untuk tingkat hutang $(\mathrm{TH})$ sebesar 0.047 lebih kecil dari $\alpha(0.05)$ dengan nilai koefisien sebesar 0.1186094, maka tingkat hutang (TH) secara individual terdapat pengaruh yang signifikan terhadap persistensi laba pada perusahaan jasa sub sektor konstruksi dan bangunan yang daftar di BEI periode 2013-2016. Hal ini menunjukkan jika tingkat hutang mengalami kenaikan sebesar 1\% maka akan menaikkan persistensi laba sebesar 0.1186094 . Hasil penelitian ini didukung oleh penelitian Septavita (2016), bahwa tingkat hutang secara individual berpengaruh terhadap persistensi laba.

Hasil penelitian ini menunjukkan bahwa semakin tinggi utang yang dimiliki perusahaan maka akan semakin tinggi persistensi labanya atau kemampuan perusahaan untuk mempertahankan jumlah laba yang diperoleh saat ini sampai masa mendatang. Hal ini dapat dilihat dari tabel 4.1 bahwa banyaknya data perusahaan sampel yang tingkat hutangnya berada diatas nilai rata-rata, yaitu sebanyak 33 data sampel. Hasil penelitian ini diperkuat oleh Fanani (2010) yang menyatakan bahwa tingkat hutang perusahaan yang besar akan menyebabkan perusahaan meningkatkan persistensi laba dengan tujuan untuk mempetahankan kinerja perusahaan yang baik di mata auditor dan investor.

\section{PENUTUP}

\section{Kesimpulan}

Dari hasil pembahasan dapat tarik beberapa kesimpulan sebagai berikut:

1. Arus kas kegiatan operasi tidak terdapat pengaruh yang signifikan terhadap persistensi laba pada perusahaan jasa sub sektor konstruksi dan bangunan yang terdafdar di BEI periode 2013-2016. Hal ini disebabkan pada perusahaan sampel lebih sering terjadi pengeluaran daripada pemasukkan kas dikarenakan metode pengakuan pendapatan.

2. Siklus operasi tidak terdapat pengaruh yang signifikan terhadap persistensi laba pada perusahaan jasa sub sektor konstruksi dan bangunan yang terdafdar di BEI periode 2013-2016. Tidak adanya pengaruh yang signifikan dikarenakan perusahaan sampel mengalami pencairan dana dalam waktu yang lama biasa disebabkan oleh proyek yang pengerjaannya lebih dari satu periode.

3. Ukuran perusahaan tidak terdapat pengaruh yang signifikan terhadap persistensi laba pada perusahaan jasa sub sektor konstruksi dan bangunan yang terdafdar di BEI periode 2013-2016. Hal ini dikarenakan para investor mengasumsikan perusahaan yang besar belum tentu menghasilkan laba yang besar, mereka lebih memilih melihat nilai pasar.

4. Tingkat hutang terdapat pengaruh yang signifikan terhadap persistensi laba pada perusahaan jasa sub sektor konstruksi dan bangunan yang terdafdar di BEI periode 2013-2016. Tingkat hutang yang tinggi akan meningkatkan persistensi labanya dengan tujuan untuk untuk mempertahankan kinerja perusahaan yang baik dimata auditor dan investor.

5. Arus kas kegiatan operasi, siklus operasi, ukuran perusahaan, dan tingkat hutang secara simultan terdapat pengaruh yang signifikan terhadap persistensi laba pada perusahaan jasa sub sektor konstruksi dan bangunan yang terdafdar di BEI periode 2013-2016.

Jadi, dapat disimpulkan bahwa arus kas kegiatan operasi, siklus operasi, ukuran perusahaan tidak terdapat pengaruh yang signifikan terhadap persistensi laba sedangkan tingkat hutang terdapat pengaruh yang signifikan terhadap persistensi laba pada perusahaan jasa sub sektor konstruksi dan bangunan periode 2013-2016. Hasil tersebut sebagian dipengaruhi oleh metode pengakuan pendapatan yang digunakan oleh khususnya 


\section{Vol. 3 No. 1 Februari 2019}

perusahaan konstruksi yaitu metode kontrak selesai dan metode persentase penyelesaian.

\section{Saran}

Berdasarkan kesimpulan yang telah dijelaskan diatas, sehingga saran-saran yang dapat penulis berikan yaitu:

1. Penelitian selanjutnya dapat mencoba melakukan penelitian dengan tahun pengamatan yang lebih lama.

2. Penelitian selanjutnya diharapkan untuk melakukan penelitian dengan populasi yang lebih luas tidak hanya terbatas pada satu sub sektor perusahaan saja yaitu perusahaan jasa sub sektor konstruksi dan bangunan.

3. Penelitian ini hanya tingkat hutang yang berpengaruh signifikan terhadap persistensi laba. Oleh karena itu, bagi peneliti yang akan meneliti dengan tema yang sama. Sebaiknya mengganti atau menambah jumlah variabel independen agar hasil penelitian dapat lebih baik lagi.

\section{REFERENSI}

Amalina, Nur. (2013). "Analisis Rasio Keuangan Dalam Memprediksi Perubahan Laba : ( Studi Empiris Pada Perusahaan Manufaktur Yang Terdaftar Pada Bursa Efek Indonesia Periode Tahun 20082011)". Skripsi, Semarang, Program Sarjana (S1) pada Program Sarjana Fakultas Ekonomika dan Bisnis Universitas Diponegoro.

Anshori, M. \& Sri, I. (2006). BUKU AJAR :Metodelogi Penelitian Kuantitatif. Surabaya: Airlangga University Press.

Armaidah, Rita. (2016). "Faktor-Faktor Yang Mempengaruhi Persistensi Laba Pada Perusahaan Manufaktur Yang Terdaftar Di Bursa Efek Indonesia Tahun 2013-2015”. Universitas Maritim Raja Ali Haji.

Bursa Efek Indonesia. (2013). "Laporan Keuangan Dan Tahuna". www.idx.co.id. Diakses pada hari Jumat, 17 November 2017 jam 11:24 WIB.

Bursa Efek Indonesia. (2014).“Laporan Keuangan Dan Tahunan". www.idx.co.id. Diakses pada hari Jumat, 17 November 2017 jam 11:24 WIB.

Bursa Efek Indonesia. (2015)."Laporan Keuangan Dan Tahunan". www.idx.co.id. Diakses pada hari Jumat, 17 November 2017 jam 11:24 WIB.

Bursa Efek Indonesia. (2016).“Laporan Keuangan Dan Tahunan". www.idx.co.id. Diakses pada hari Jumat, 17 November 2017 jam 11:24 WIB.

Chowijaya, Andriansyah, dkk.(2010)."Pengaruh Laba Akuntansi, Laba Fiskal, dan Arus
Kas Operasi Terhadap Persistensi Laba", STIE Multi Data Palembang, hlm. 1-12. cnnindonesia.com/ekonomi, 17 Februari 2017.

Dewi, Ni Putu Lestari Dewi \& I.G.A.M Asri Dwija Putri. (2015). "Pengaruh Book-Tax Difference, Arus Kas Operasi, Arus Kas Akrual, dan Ukuran Perusahaan pada Persistensi Laba", dalam E-Jurnal Akuntansi Universitas Udayana, Vol.10, No.1, hlm. 244- 260.

Fahmi, Irham. (2013). Analisis Laporan Keuangan. Bandung: Alfabeta.

Fanani, Z., (2010). "Analisis Faktor-Faktor Penentu Persistensi Laba", Jurnal Akuntansi dan Keuangan Indonesia, Vol 7, No. 1, hlm. 109-123.

Hayati, Nurul \& Christina Riani. (2011). "Pengaruh Arus Kas terhadap Likuiditas Pada Perusahaan Telekomunikasi Yang Terdaftar Di BEI", dalam Jurnal Spread, Vol.1, No.1, hlm 49-61.

Ikatan Akuntan Indonesia. (2015). Standar Akuntansi Keuangan. Jakarta: Grha Akuntan.

Kusuma, Briliana \& Sadjiarto RA. (2014). "Pengaruh Volatilitas Arus Kas, Volatilitas Penjualan, Tingkat Hutang, Book-Tax Gap dan Tata Kelolah Perusahaan terhadap persistensi Laba". Universitas Kristen Petra, Tax dan Accounting Review, Vol 4, No. 1-2014.

Kusumaningtyas, Ariyanti. (2016). "Pengaruh Arus Kas Operasi, Stuktur Kepemilikan, Dan Ukuran Perusahaan Terhadap Kinerja Keuangan", dalam Jurnal Ilmu dan Riset Akuntansi, Vol 5, No. 2, hlm. 1-17.

Lestari, Ayu Zakya .(2010). "Analisis FaktorFaktor yang Mmepengaruhi Pertumbuhan Ekonomi Regional di Provinsi Jawa Barat (Periode 1995-2018)'”. Skripsi. Jakarta: Program Sarjana (S1) pada Program Sarjana Fakultas Ekonomi dan Bisnis Universitas Islam Negeri Syarif Hidayatullah.

Martani, Dwi. dkk. (2012). Akuntansi Keuangan Menegah Berbasis PSAK. Jakarta: Salemba Empat.

Nuraini, Mety. (2014). "Analisis Faktor-Faktor Penentu Persistensi Laba". Skripsi. Semarang: Prograam Sarjana (S1) pada Program Sarjana Fakultas Ekonomika dan Bisnis Universitas Diponegoro.

Prayoga, Irfan Bagus Dwi. (2012). "Pengaruh Laba Bersih Dan Komponen-Komponen Akrual Terhadap Arus Kas Aktivitas Operasi Di Masa Mendatang”. Skripsi. Semarang: Program Sarjana (S1) pada Program Sarjana Fakultas Ekonomika dan Bisnis Universitas Diponegoro . 
JURNAL TAMBORA

\section{Vol. 3 No. 1 Februari 2019}

Purwanti. (2010). “Analisis Pengaruh Volatilitas arus kas, Besaran Akrual, Volatilitas penjualan, Leverage, Siklus Operasi, Ukuran Perusahaan,Umur Perusahaan, dan Likuiditas Terhadap Kualitas Laba". Universitas Sebelas Maret, Surakarta.

Reeve, James M, dkk. Et al. (2013). Pengantar Akuntansi. Jakarta. Salemba Empat.

Romasari, Sonya. (2013). "Pengaruh Persistensi Laba, Struktur Modal, Ukuran Perusahaan dan Alokasi Pajak Antar Periode Terhadap Kualitas Laba (Studi Empiris pada Perusahaan Manufaktur yang Terdaftar di BEI)." Skripsi. Padang: Universitas Negeri Padang.

S, Azzahra Salsabiila. (2016). "Pengaruh Book Tax Differences Dan Aliran Kas Operasi Terhadap Persistensi Laba" dalam Jurnal Akuntansi, Vol XX, No. 02, hlm. 314-329.

Samisi, K., \& Ardiana. (2013). Pengaruh Struktur Pendanaan Terhadap Nilai Perusahaan Dengan Kepemilikan Manajerial Sebagai Variabel Moderasi. E-Jurnal Akuntansi Universitas Udayana, 451-469.

Saputera, Erwin Nahdi, dkk. (2017). "Pengaruh Book Tax Differences Dan Aliran Kas Operasi Terhadap Persistensi Laba" dalam Jurnal e-Proceeding of Management, Vol.4, No.1, hal. 523-532.

Sari, Sandhiny Permata. (2016). "Pengaruh Aliran Kas, Leverage, Book Tax Difference Terhadap Persistensi Laba Dengan Komponen Laba Akrual Sebagai Variabel Moderasi Pada Perusahaan Property Dan Realestate Yang Terdaftar Di Bursa Efek
Indonesia”. Skripsi. Semarang: Gelar Sarjana Ekonomi pada Universitas Negeri Semarang.

Septavita, Nurul. (2016). "Pengaruh Tax Differences, Arus Kas Operasi, Tingkat Hutang, Ukuran Perusahaan Terhadap Persistensi Laba",Vol.3, No.1, hlm 13091323.

Sukman. (2017). "Pengaruh Arus Kas Operasi, Tingkat Utang, Dan Ukuran Perusahaan Terhadap Persistensi Laba Dengan Book Tax Differences Sebagai Variabel Moderating”. Skripsi. Makassar: Program Sarjana (S1) Ekonomi Jurusan Akuntansi pada Fakultas Ekonomi dan Bisnis Islam UIN Alauddin Makassar.

Sulastri, A. Desra, (2010). "Pengaruh Volatilitas Arus Kas, Volatilitas Penjualan,Besaran Akrual dan Tingkat Hutang terhadap Persistensi Laba", Program studi Akuntansi Fakultas Ekonomi Universitas Negeri Padang.

Susilo, Tri Pujadi \& Btari Mutia Anggraeni. (2015). “Analisis Pengaruh Volatilitas Arus Kas, Tingkat Utang, Siklus Operasi, Dan Ukuran Perusahaan Terhadap Persistensi Laba," hlm. 4-21.

Suwanrdi, Akbar. (2011). "Tahapan dan Perntah Syntax Data Panel". Modul, Universitas Indonesia, Depok.

Taures, Nazila Sofi Istna. (2011). “Analisis Hubungan Antara Karakteristik Perusahaan dengan Pengungkapan Risiko". Universitas Diponegoro Semarang. 